\title{
LLNL Measurements of Graded-Index Multi-Mode Optical Fiber (ITF 47)
}

\author{
T. T. Saito
}

May 1, 2000

Lawrence

Livermore

National

Laboratory 


\section{DISCLAIMER}

This document was prepared as an account of work sponsored by an agency of the United States Government. Neither the United States Government nor the University of California nor any of their employees, makes any warranty, express or implied, or assumes any legal liability or responsibility for the accuracy, completeness, or usefulness of any information, apparatus, product, or process disclosed, or represents that its use would not infringe privately owned rights. Reference herein to any specific commercial product, process, or service by trade name, trademark, manufacturer, or otherwise, does not necessarily constitute or imply its endorsement, recommendation, or favoring by the United States Government or the University of California. The views and opinions of authors expressed herein do not necessarily state or reflect those of the United States Government or the University of California, and shall not be used for advertising or product endorsement purposes.

Work performed under the auspices of the U.S. Department of Energy by the University of California Lawrence Livermore National Laboratory under Contract W-7405-Eng-48.

This report has been reproduced directly from the best available copy.

Available to DOE and DOE contractors from the

Office of Scientific and Technical Information

P.O. Box 62, Oak Ridge, TN 37831

Prices available from (423) 576-8401

http://apollo.osti.gov/bridge/

Available to the public from the

National Technical Information Service

U.S. Department of Commerce 5285 Port Royal Rd., Springfield, VA 22161 http://www.ntis.gov/

OR

Lawrence Livermore National Laboratory

Technical Information Department's Digital Library

http://www.llnl.gov/tid/Library.html 


\section{LLNL Measurements of Graded-Index Multi-Mode Optical Fiber (ITF 47)}

\section{May 2000}

\section{Theodore T. Saito}




\title{
LLNL Measurements of Graded-Index Multi-Mode Optical Fiber (ITF 47)
}

\author{
T. T. Saito
}

May 1, 2000

Lawrence

Livermore

National

Laboratory 


\section{DISCLAIMER}

This document was prepared as an account of work sponsored by an agency of the United States Government. Neither the United States Government nor the University of California nor any of their employees, makes any warranty, express or implied, or assumes any legal liability or responsibility for the accuracy, completeness, or usefulness of any information, apparatus, product, or process disclosed, or represents that its use would not infringe privately owned rights. Reference herein to any specific commercial product, process, or service by trade name, trademark, manufacturer, or otherwise, does not necessarily constitute or imply its endorsement, recommendation, or favoring by the United States Government or the University of California. The views and opinions of authors expressed herein do not necessarily state or reflect those of the United States Government or the University of California, and shall not be used for advertising or product endorsement purposes.

Work performed under the auspices of the U.S. Department of Energy by the University of California Lawrence Livermore National Laboratory under Contract W-7405-Eng-48.

This report has been reproduced directly from the best available copy.

Available to DOE and DOE contractors from the

Office of Scientific and Technical Information

P.O. Box 62, Oak Ridge, TN 37831

Prices available from (423) 576-8401

http://apollo.osti.gov/bridge/

Available to the public from the

National Technical Information Service

U.S. Department of Commerce 5285 Port Royal Rd., Springfield, VA 22161 http://www.ntis.gov/

OR

Lawrence Livermore National Laboratory

Technical Information Department's Digital Library

http://www.llnl.gov/tid/Library.html 


\section{LLNL Measurements of Graded-Index Multi-Mode Optical Fiber (ITF 47)}

\section{May 2000}

\section{Theodore T. Saito}


Lawrence Livermore National Laboratory Measurement of VNIITF Fiber ITF 10.2

\author{
Introduction \& Summary
}

\title{
Background
}

The Russian Federal Nuclear Center -All Russian Research Institute of Technical Physics, located in the Nuclear City of Snezhinsk, east of the Ural mountains and the Lawrence Livermore National Laboratories have been investigating the possibility of establishing a commercial optical fiber manufacturing facility. These discussions began in the summer of 1998. At that time three samples (single mode and multi-mode) of optical fiber were left at the Sandia National Laboratory. Sandia measured two of the segments and sent them to LLNL. The optical loss at $1550 \mathrm{~nm}$ and $1300 \mathrm{~nm}$ were higher than commercially available fiber. The measurements were complicated because the geometry of the fibers also did not meet specification. Since the core was not adequately centered coupling of optical energy into the fiber being tested varied widely depending on which end of the fiber was used for insertion. The results of these measurements were summarized in the informal report dated June 11, 1999, which was hand carried by Dr. Paul Herman during his July 1999 visit.

During the July visit a 1.2-km long section of graded-index multimode fiber, ITF 47, was given to Herman. We had requested samples longer than the earlier ones (which were $\sim 0.1 \mathrm{~km}$ long) in order that a cutback method could be used for the transmission measurements.

\section{Measurements Summary}

The optical loss using the cutback technique and the transmission spectral measurements in the $600-1700 \mathrm{~nm}$ region are reported. Also physical measurements are reported of the fiber's diameter, concentricity, ellipticity and tensile strength (proof test). The test results are summarized in Table 1, "Comparative Data for Multi-mode Optical Fiber." The table includes the values from the Industrial specification TIA/EIA 402AAAB, the commercial specification for Corning's 50/125 CPC6, the values measured on ITF-47 and provided by C-70, and LLNL's values for ITF-47 as well as the multimode values from the June 1999 samples.

\section{Physical measurements}

Proof Test (Tensile Test) -Set-up

A $10 \mathrm{~m}$ long section of the optical fiber was tested on an Instron 1122 test system at a rate of $12.7 \mathrm{~mm} / \mathrm{min}$ in late September 1999 . The load was measured with the $20-\mathrm{lb}$. range and displacement was calculated from the motion of the crosshead. Five fiber locations were randomly selected from locations within the roll and measured for diameter using a Zygo 1200 Laser, and the outer diameter of the fiber, that is the coating, is given in Table 2. Fiber specimens were gripped with Instron series 2714 pneumatic cord and yarn grips. To minimize crushing of the optical fiber, vinyl tape was applied to grip faces to distribute stress. Grip air pressure of 15 psig was used. 
Table 1 - Comparative Data for Multi-mode Optical Fiber

\begin{tabular}{|c|c|c|c|c|c|}
\hline Specification & $\begin{array}{c}\text { TIA/EIA } \\
\text { 402AAAB } \\
\text { Industrial spec }\end{array}$ & $\begin{array}{c}\text { "Corning" } \\
\text { 50/125 CPC6 }\end{array}$ & $\begin{array}{c}\text { ITF-47 } \\
\text { C-70 } \\
\text { Values } \\
\end{array}$ & $\begin{array}{l}\text { ITF-47 } \\
\text { LLNL } \\
\text { Values }\end{array}$ & $\begin{array}{c}\text { ITF-10.2 } \\
\text { Multimode } \\
\text { LLNL }\end{array}$ \\
\hline 1 & 2 & 3 & 4 & 5 & 6 \\
\hline 1. Core Diameter, $\mu \mathrm{m}$ & $50.0 \pm 3.0$ & $50.0 \pm 3.0$ & 51 & $53 \pm 2$ & \\
\hline 2. Cladding Diameter, $\mu \mathrm{m}$ & $125.0 \pm 2.0$ & $125.0 \pm 2.0$ & 127 & $128 \pm 1$ & \\
\hline 3. Coating Diameter, $\mu \mathrm{m}$ & $250.0 \pm 15.0$ & $245.0 \pm 10.0$ & 270 & $270 \pm 6^{* * *}$ & \\
\hline 4. Core-Clad Concentricity, $\mu \mathrm{m}$ & $\leq 3.0$ & $\leq 3.0$ & & 0.7 & \\
\hline 5. Coating-Cladding Concentricity, $\mu \mathrm{m}$ & $\leq 20$ & $\leq 12$ & & & \\
\hline 6. Cladding Non-Circularity, $\%$ & $\leq 2.0$ & $\leq 2.0$ & 4 & 0.7 & \\
\hline 7. Core Non-Circularity, $\%$ & $\leq 6.0$ & $\leq 5.0$ & 4 & 0.8 & $\sim 14$ \\
\hline 8. Standard Length, $M$ & $1100-4400$ & $1100-4400$ & 1300 & & \\
\hline 9. Proof Test, Gpa & $\geq 0.69$ & $\geq 0.7$ & 0.4 & 0.9 & \\
\hline 10. Attenuation, $\lambda=850 \mathrm{~nm}, \mathrm{~dB} / \mathrm{km}$ & $\leq 3.0$ & $\leq 2.5$ & 3.0 & $7 @ 830 \mathrm{~nm}$ & \\
\hline 11. Attenuation, $\lambda=1300 \mathrm{~nm}, \mathrm{~dB} / \mathrm{km}$ & $\leq 1.0$ & $\leq 0.8$ & 1.2 & $5 * * * *$ & \\
\hline 12. Attenuation, $\lambda=1380 \mathrm{~nm}, \mathrm{~dB} / \mathrm{km}$ & $\leq 3.0$ & $\leq 2.0$ & 9.0 & $16^{* * * *}$ & $\begin{array}{c}2.4 @ \\
1550 \mathrm{~nm} \\
\end{array}$ \\
\hline 13. Bandwidth, $\lambda=850 \mathrm{~nm}, \mathrm{MHz}-\mathrm{km}$ & $\geq 400$ & 500 & 380 & $\begin{array}{l}1,100 \mathrm{MHz}- \\
\mathrm{km} @ 832 \mathrm{~nm}\end{array}$ & \\
\hline 14. Bandwidth, $\lambda=1300 \mathrm{~nm}, \mathrm{MHz}-\mathrm{km}$ & $\geq 400$ & 500 & 500 & & \\
\hline 15. Zero Dispersion Wavelength, $\mathrm{nm}$ & $1295-1320$ & $1297-1316$ & & & \\
\hline 16. Zero Dispersion Slope, $\mathrm{pc} / \mathrm{nm}^{2} \cdot \mathrm{km}$ & \begin{tabular}{|l|}
$\leq 0.11 \pi \mathrm{J} 1 \mathrm{R}$ \\
$1300-1320$ \\
\end{tabular} & \begin{tabular}{|l|}
$\leq 0.11 \pi \mathrm{J} 1 \mathrm{R}$ \\
$1297-1316$ \\
\end{tabular} & & & \\
\hline 17. Numerical Aperture & $0.200 \pm 0.015$ & $0.200 \pm 0.012$ & 0.2 & & \\
\hline
\end{tabular}


Sample ITF-47 is the multimode fiber that Paul Herman brought back from his July 1999 visit to Snezhinsk.

(1) C-70 Value, are the measurement data given to Paul with the sample. We understand that C-70 some of these measurements were made for $\mathrm{C}-70$ by an organization in or near Moscow.

(2) LLNL Values: are the data taken by LLNL.

ITF-10.2 is the multimode fiber that Paul Herman brought back from his November 1998 visit. The table sent in November 1999 had a mistake for the ITF 10.2 attenuation. The attenuation was $2.4 \mathrm{db} / \mathrm{km}$ at $1550 \mathrm{~nm}$. The value of $80 \mathrm{db} / \mathrm{km}$ at $1550 \mathrm{~nm}$ was for the multimode optical fiber brought by the C-70 delegation to Sandia Laboratory in August of 1998. The data from the ITF 10.2 and the single and multi-mode fiber from August 1998 was summarized in a report "C-70 Optical Fiber Measurements \& Analysis" 11 June 1999 which Paul Herman delivered to Snezhinsk during his July 1999 visit. 


\section{Test Procedure}

Five one-meter length samples were cut from the roll of optical fiber. One end of the fiber was then connected to the upper grip on the Instron test machine. The crosshead was lowered until there was 0.5 meters between the upper and lower grip. (gage length of 0.5 meters). The lower grip was attached. Data acquisition was started and the test ran until specimen failure. Typical measurements are on much longer (10's $\mathrm{m}$ ) special fiber testing machine. These tests on shorter sections yield higher values

The ultimate strength was calculated using the average of the measured fiber diameter, Table 3. Please see Figure 1 for stress vs. strain curves of the five samples tested. Strain is defined as the grip separation $(0.5 \mathrm{~m})$ divided by total crosshead motion.

Table 2 Optical Fiber Coating Diameter

\begin{tabular}{|c|c|}
\hline Sample & Diameter $(\mu \mathbf{m})$ \\
\hline 1 & 268.5 \\
\hline 2 & 265.1 \\
\hline 3 & 269.2 \\
\hline 4 & 280.7 \\
\hline 5 & 266.1 \\
\hline Average & $\mathbf{2 6 9 . 9}$ \\
\hline Standard Dcv. & $\mathbf{6 . 2}$ \\
\hline
\end{tabular}

Table 3 Optical Fiber Ultimate Strength

\begin{tabular}{|c|c|}
\hline Sample & Ultimatc Strength (Gpa) \\
\hline 1 & 0.957 \\
\hline 2 & 0.956 \\
\hline 3 & 0.948 \\
\hline 4 & 0.958 \\
\hline 5 & 0.944 \\
\hline Average & $\mathbf{0 . 9 5 3}$ \\
\hline Standard Dev. & $\mathbf{0 . 0 0 6}$ \\
\hline
\end{tabular}

Core and Cladding diameter

The attenuation of the fiber was measured using the cutback technique as described in the next section. Ten different measurements were made after cutting off a length of the fiber. The core and cladding of the fiber was measured on an optical microscope as each section of the fiber was removed. The maximum diameter was measured, and the diameter approximately perpendicular to the maximum was measured. The maximum was estimated first by eye and then measured. When a doubt existed if the diameter was the maximum, another measurement or two was made. The results for the core and cladding diameter and non-circularity are given as a function of length of where 
the measurement is made in Table $4 \& 5$. The non-circularity is calculated using equation 1 in the same manner as in the standard TLA/EIA-492AAAB (50 $\mu \mathrm{m}$ core, $125 \mu \mathrm{m}$ cladding diameter).

(3) Non-circularity $=[1-\{\text { min diameter/maximum diameter }\}]^{*} 100$

Table 4 Cladding Diameter and Non-Circularity as a Function of Position

\begin{tabular}{|c|r|r|r|c|}
\hline $\begin{array}{c}\text { Position } \\
(\text { Length })(\mathrm{m})\end{array}$ & $\begin{array}{c}\text { Cladding 1 } \\
(\mu \mathrm{m})\end{array}$ & $\begin{array}{c}\text { Cladding 2 } \\
(\mu \mathrm{m})\end{array}$ & $\begin{array}{c}\text { Ellipticity- } \\
\text { Cladding1/ } \\
\text { Cladding2 }\end{array}$ & $\begin{array}{c}\text { Non } \\
\text { Circularity }\end{array}$ \\
\hline 126 & 127.2 & 129.1 & 0.985 & 1.472 \\
\hline 224 & 128.8 & 128.9 & 0.999 & 0.078 \\
\hline 324 & 127.4 & 128.4 & 0.992 & 0.779 \\
\hline 422 & 127.4 & 125.8 & 1.013 & 1.272 \\
\hline 518 & 126.8 & 127.3 & 0.996 & 0.393 \\
\hline 616 & 128.8 & 130.3 & 0.988 & 1.151 \\
\hline 712 & 126.7 & 125.9 & 1.006 & 0.635 \\
\hline 815 & 128.1 & 129.7 & 0.988 & 1.234 \\
\hline 907 & 127.9 & 127.8 & 1.001 & 0.078 \\
\hline 1215 & 129.1 & 129.7 & 0.995 & 0.463 \\
\hline & & & & \\
\hline Average & 128.1 & & & 0.76 \\
\hline Std Dev & 1.3 & & & 0.51 \\
\hline
\end{tabular}

Table 5 Core Diameter, Non-Circularity, and Center Off-set as a Function of Position

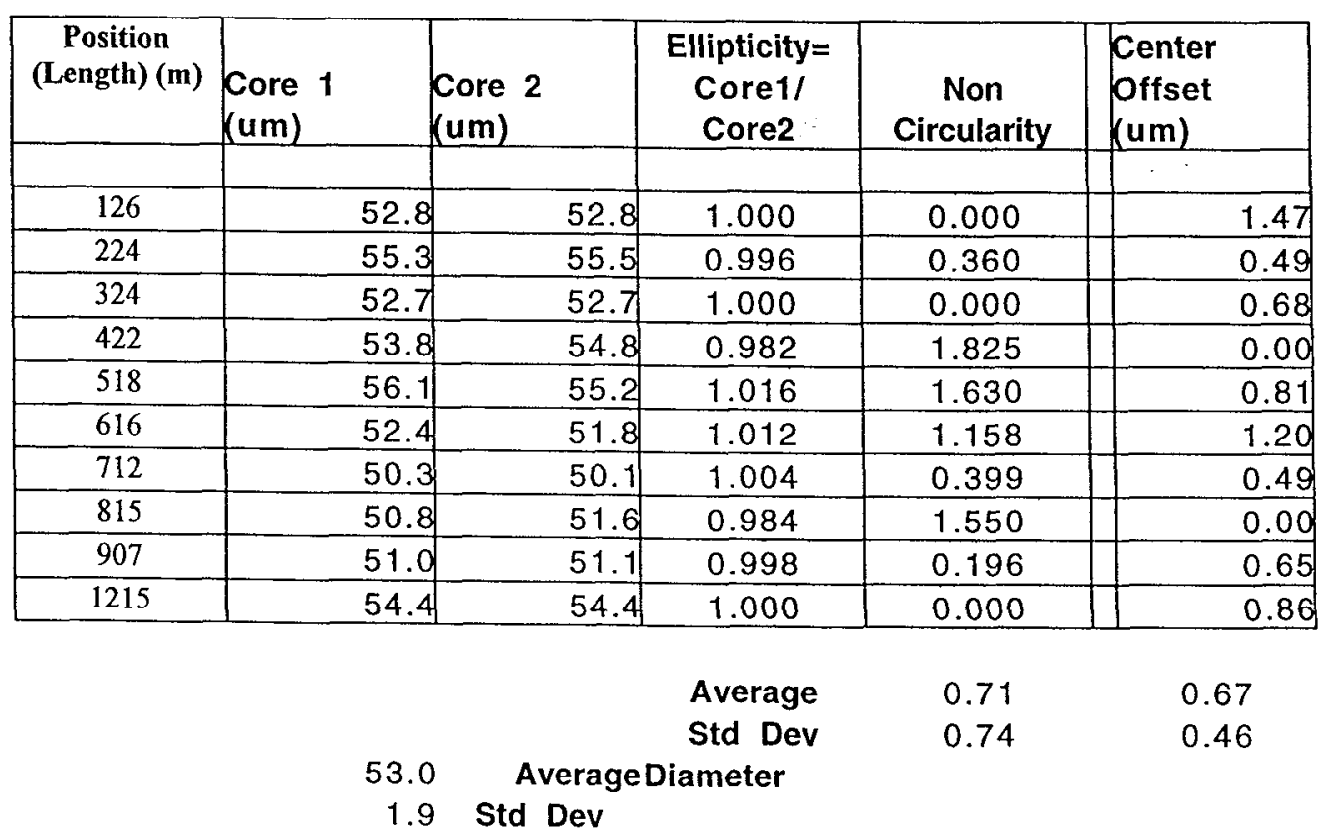


Figure 1 Stress vs Strain

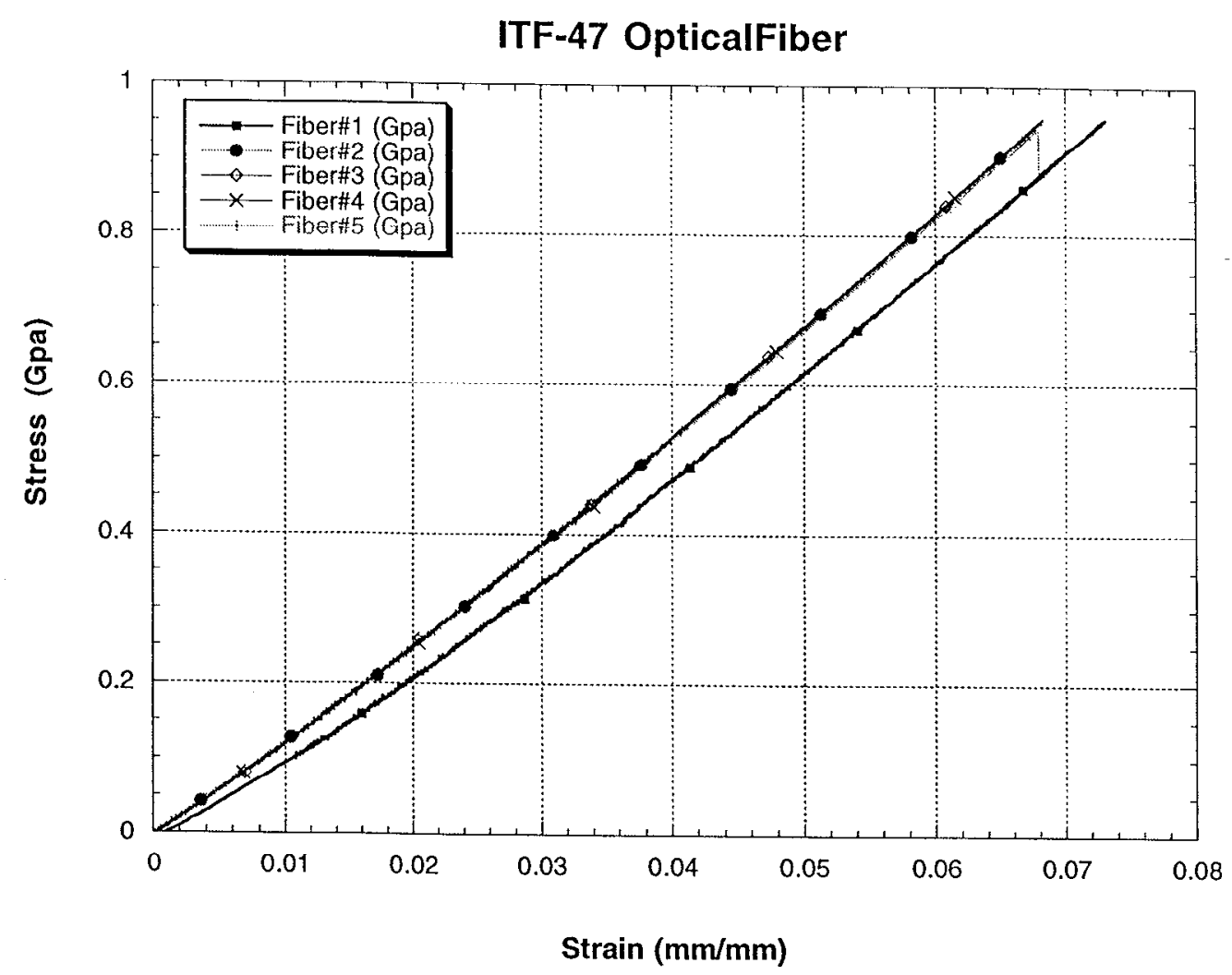

report v5 